\title{
TXNRD2 wt Allele
}

National Cancer Institute

\section{Source}

National Cancer Institute. TXNRD2 wt Allele. NCI Thesaurus. Code C107620.

Human TXNRD2 wild-type allele is located in the vicinity of 22q11.21 and is approximately $66 \mathrm{~kb}$ in length. This allele, which encodes thioredoxin reductase 2, mitochondrial protein, plays a role in thioredoxin redox potential. 